\title{
海洋短波レーダー観測結果を用いた東京湾に おける漂流ゴミの輸送経路・流入期間の推定
}

\author{
森谷 拓実 1 村上 和男 2 \\ 1学生会員 東京都市大学大学院 工学研究科 都市工学専攻（广158-8557 東京都世田谷区玉堤1-28-1） \\ E-mail:g1281718@tcu.ac.jp \\ 2フェロー 工(博) 東京都市大学教授 工学部 都市工学科（†158-8557 東京都世田谷区玉堤1-28-1） \\ E-mail:kmuraka@tcu.ac.jp
}

\begin{abstract}
海域の漂流ゴミは経済活動，環境への悪影響をもたらす。したがって，効率的な早期回収が課題であり， 流入源・輸送経路の把握が重要である. 本研究では東京湾内の漂流ゴミについて, 沿岸に設置された海洋 短波レーダー（HFレーダー）による観測結果と漂流ゴミ回収船「べいくりん」の回収記録を用いて分析 を行った．漂流ゴミの輸送を移流拡散現象として，計算上で仮想ゴミ（質量がゼロの粒子）を用いて算定 した。計算結果と「べいくりん」の回収記録の整合性を確認し，仮想ゴミが回収エリアに到達する放流日 時より各流入源からの流入期間を算出した。漂流ゴミの輸送経路・流入期間が推定でき，回収記録との整 合性も概ね良好であった。 HFレーダーの表層流況データによる, 漂流ゴミの輸送経路の予測, 及び予測 結果の漂流ゴミ回収への利用の可能性が示唆された。
\end{abstract}

Key Words : High frequency radar, Drifting garbage, Advective, Diffusion, Tokyo Bay

\section{1. はじめに}

東京湾をはじめ様々な海域において，海域の漂流ゴミ 等は船舶航行の妨げや沿岸環境の悪化をもたらす原因の 一つである. したがって効率の良い早期回収が課題であ り，そのためには漂流ゴミの流入源や流入時期，輸送経 路の把握が重要である．漂流ゴミ等の輸送は表層流（深 度約 $0.5 \mathrm{~m}$ までの流れ）により決定されるので, 表層流 を広範囲かつ常時観測が可能である海洋短波レーダー

(High Frequency Rader，以下HFレーダー) の利用が有効 であると考えられる。

東京湾では国土交通省により沿岸に設置された，3台 のHFレーダーにより湾内の表層流況が観測されている. また，同省の清掃兼油回収船「べいくりん」を始め，多 くのゴミ回収作業船により年間平均 $8,500 \mathrm{~m}^{3}(2004-2008)^{1)}$ の漂流ゴミの回収が行われている.これら湾内の漂流ゴ ミの輸送特性として,

・多くが河川起源であり，降雨後など出水時に輸送量が 卓越する2),

・海面の収束部に集積され易いぶ,

と報告されている.

本研究では漂流ゴミの集積位置を予測するような，漂 流ゴミ回収を早期化・効率化する回収支援システムの高
度化を最終的な目的としている. その基礎的な研究とし て，東京湾におけるHFレーダーの観測結果から漂流ゴ ミの輸送経路・流入期間の推定を行い, 漂流ゴミ回収記 録との比較・検討を行った.

\section{HFレーダーの概要}

HFレーダーは海洋レーダーの一種であり, 短波帯の 電波を用いて表層流況を観測できるリモートセンシング 機器である. 図-1に海洋レーダーによる表層流の測定原 理を示す．レーダー波を海面に照射すると，レーダー波 の1/2の波長を持つ成分が海面波と共鳴し，ブラッグ共 鳴散乱が生じる. この後方散乱波を受信し, 解析寸るこ とにより表層流速を得る.

従来の定点観測型の流速計に比べ，海洋レーダーは広 範囲かつ面的な観測が常時可能であり，維持管理が容易 という利点がある。またHFレーダーの観測精度に関し ては，伊勢湾及び三河湾で行われた，沿岸に設置された HFレーダーの観測結果と, GPS送受信機を搭載した漂流 ボトルの移動速度の比較検証から，良い相関が報告され ている゙)。これより，漂流ゴミの輸送を追跡・予測する のにHFレーダーの観測結果を用いるのは有効である. 


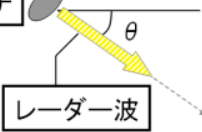

ブラッグ共鳴散乱された後方散乱波

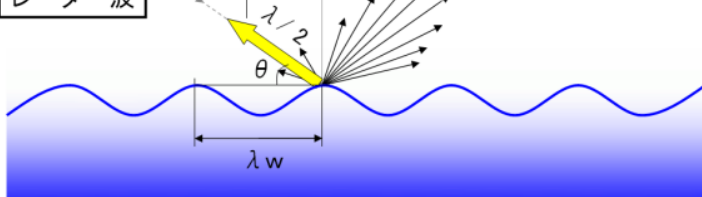

図-1 海洋レーダーの測定原理

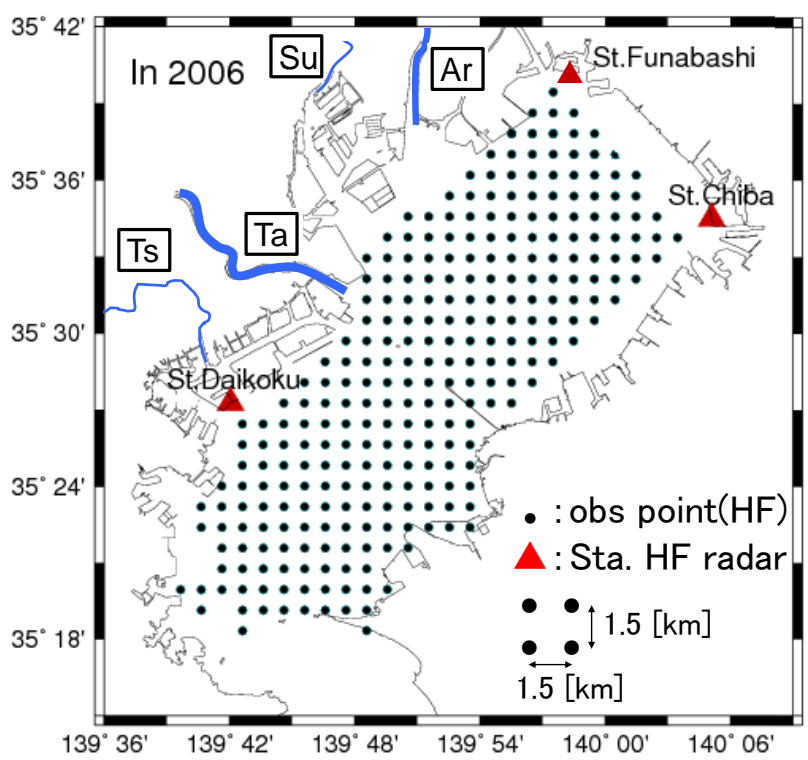

図-2 2006年 HF レーダーの観測範囲

$\Delta: \mathrm{HF} レ$ ーダーの設置地点，・：表層流の解析点

\section{3. 使用データ}

本研究では国土交通省が行っている東京湾における HFレーダーによる表層流況の観測データと，同省の清 掃兼油回収船「べいくりん」による漂流ゴミ回収記録を 用いて分析を行った. 以下に各データの詳細を示寸.

\section{（1） 表層流況データ}

本研究では2006年4月〜2007年12月までの1時間毎の時 系列表層流況データ5)を用いた．図-2に2006年の東京湾 におけるHFレーダーの観測局（ム）と表層流の解析点 (•)を示寸，図中のTa，Su，Ar，Tsはそれぞれ多摩川，隅 田川，荒川，鶴見川を示す．各観測局の設置地点（山） は神奈川県横浜市鶴見区大黒頭，千葉県船橋市潮見町 船橋，千葉県千葉市中央区川崎町である。観測範囲は観 測局から約 $1.5 \mathrm{~km} \sim 60 \mathrm{~km}$ 程度で，1.5 kmメッシュのデー タが1時間毎に観測されている．流速の解析点(•)は国土 交通省により整理されており，2006年は287地点，2007 年は241地点と数が異なっている，観測された表層流況 は東京湾環境情報センターがWebに一般公開している5
表-1 研究対象の回収日

\begin{tabular}{l|l|l}
\hline \multirow{2}{*}{ 回収日 } & 2006 & $8.10 \sim 11,9.27 \sim 29,10.4 \sim 6$ \\
\cline { 2 - 3 } & 2007 & $4.23 \sim 25,5.28 \sim 6.1$ \\
\hline
\end{tabular}

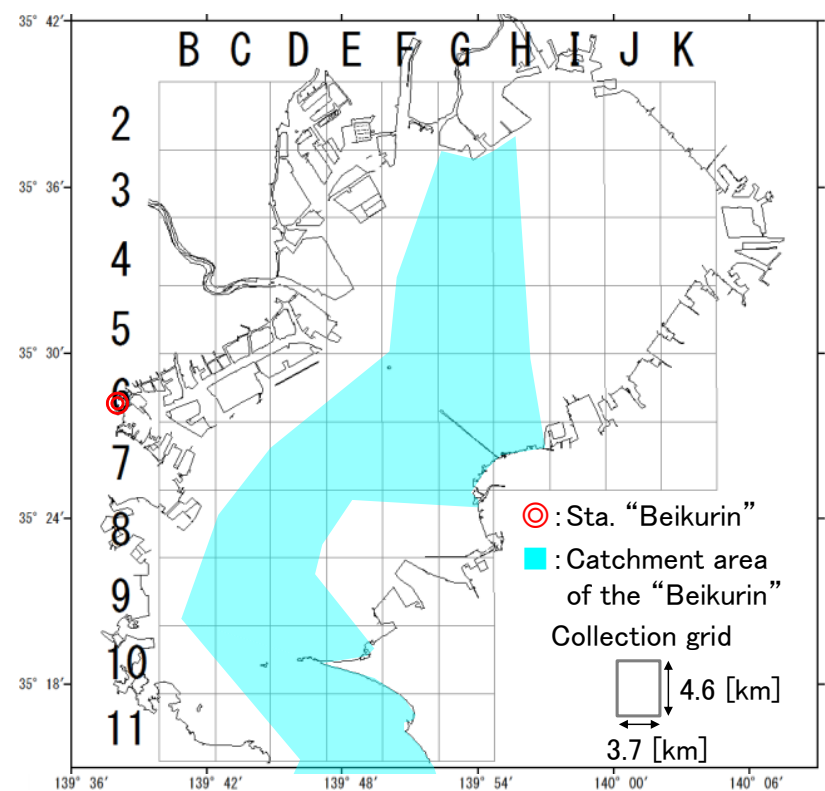

図-3「べいくりん」管轄区域と回収エリアのグリッド

\section{（2）漂流ゴミ回収データ}

表-1に本研究で対象とした漂流ゴミ回収日を，図-3に 「べいくりん」の管轄区域である東京湾の一般海域の一 部と，回収エリアのグリッドを示寸．漂流ゴミ回収デー 夕には，河川出水時の輸送特性を考慮し，1～3日前に降 雨が確認された計16日間の回収日を用いた。この16日間 に回収された漂流ゴミの種類別割合を調べた結果,

「蕫・草」，「木材・木片」，「竹」，「海草」，「ビ ニール類」が全回収量の $93.2 \%$ を占めていた。これらは 漂流時に水面上へ露出する部分が小さいため, 風による 影響が小さいゴミである゙.

\section{4. 分析手法}

\section{（1）計算モデル}

漂流ゴミの輸送を，流れによる作用，風による作用， 拡散の3つからなる移流拡散現象として式(1a)，(1b)で 表した.

$$
\begin{aligned}
& x_{t+1}=x_{t}+a_{1} v_{e l} l_{x t} \Delta t+a_{2} w_{x t} \Delta t+a_{3} l_{x t} \\
& y_{t+1}=y_{t}+a_{1} \operatorname{vel}_{y t} \Delta t+a_{2} w_{y t} \Delta t+a_{3} l_{y t}
\end{aligned}
$$

式(1a)において， $x_{1}$ は基点からの東西方向距離 $[\mathrm{m}]$, $v e l_{x}$ はHFレーダー観測データを用いて算出した東西方向 
推定流速 $[\mathrm{m} / \mathrm{s}], \quad w_{x x}$ は東西方向風速 $[\mathrm{m} / \mathrm{s}], \quad l_{x}$ はランダムウ オークにより決定される拡散の東西方向成分 [m] $, a_{1}, a_{2}$, $a_{3}$ はパラメーターである。 それぞれの值は，漂流ゴミは 表層流により運ばれるので $a_{1}=1$, 回収された漂流ゴミ の種類の割合から風圧流の影響は無しとしたので $a_{2}=0$, $a_{3}$ は複数回の計算より得た最適值 $(=0.02)$ を用いた. HFレ

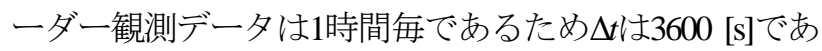
る. 同様に式(1b) は南北方向成分を表す.

漂流ゴミの輸送における, 漂流物の水面下に働く流れ (潮流，吹送流，恒流，密度流，海流）による運動には， HFレーダーの観測結果を用いた。 なお，HFレーダーの 観測点は図-2の点(•で表された場所である. 図-4に示す ように，漂流ゴミの輸送地点付近の観測点を近い順に5 地点選出寸る. そして, 各観測点の流速から距離に重み を付けて平均し, 輸送地点の流速ベクトルを算定した. 算定に用いた式(2a)，(2b)を示す.

$$
\begin{aligned}
& v_{e} l_{x}=\frac{\sum U_{i} L_{i}^{-2}}{\sum L_{i}^{-2}} \\
& v e l_{y}=\frac{\sum V_{i} L_{i}^{-2}}{\sum L_{i}^{-2}}
\end{aligned}
$$

式(2a)において，vel は東西方向推定流速 $[\mathrm{m} / \mathrm{s}] ， U_{i}$ は 各観測点のHFレーダー観測データの東西方向流速 $[\mathrm{m} / \mathrm{s}]$, $L_{i}$ は各観測点と輸送地点との距離 $[\mathrm{m}]$ を表す，同様に式 (2b) は南北方向成分を表す.

漂流ゴミの拡散はランダムウォークの概念を用いた. ここでは拡散係数に正規乱数を掛けた值で拡がると仮定 した ${ }^{7}$ ，算出に用いた式(3a)，(3b)，式 (4a)，(4b)，式 (5a)， (5b)を示す.

$$
\begin{gathered}
l_{x t}=c_{x} a \\
l_{y i}=c_{y} b \\
c_{x}=\sqrt{24.0 \times \Delta t \times K_{x}}
\end{gathered}
$$

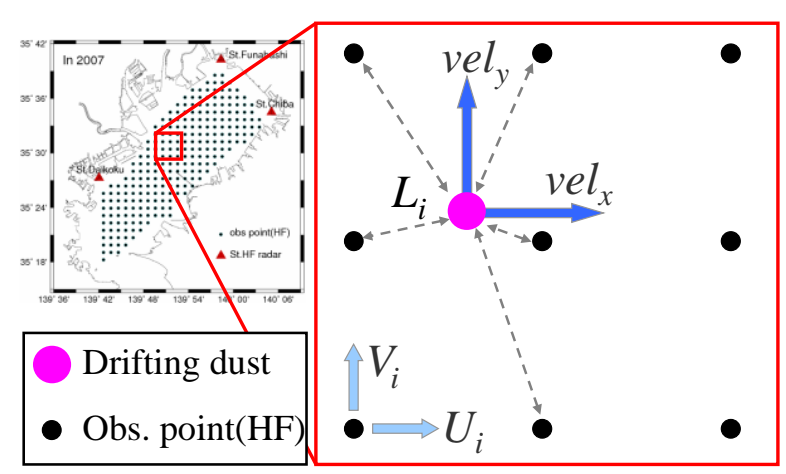

図-4 漂流ゴミの移流速度の算定法

$$
\begin{gathered}
c_{y}=\sqrt{24.0 \times \Delta t \times K_{y}} \\
K_{x}=\frac{5.93 \times \mid \text { vel }_{x} \mid}{20.0} \times \text { depth } \\
K_{y}=\frac{5.93 \times \mid \text { vel }_{y} \mid}{20.0} \times \text { depth }
\end{gathered}
$$

式(3a)，(4a)，(5a)において $l_{x}$ は東西方向の拡散成分 [m], $c_{x}$ は時刻・粒子によらない係数, $a, b$ は[-0.5,0.5]の範囲 の正規乱数, $K_{x}$ は東西方向拡散係数 $\left[\mathrm{m}^{2} / \mathrm{s}\right], v e l_{x}$ は東西方 向推定流速 $[\mathrm{m} / \mathrm{s}]$, depth は東京湾の平均水深 $(=15 \mathrm{~m}), \mathrm{HF}$ レーダー観測データの整理の関係から $\Delta t$ は $3600[\mathrm{~s}]$ であ る. 同様に式(3b)，(4b)，(5b) は南北方向成分を表す. 水平拡散係数は Elderの拡散係数の式を用いた.

$$
K=5.93 U_{*} h
$$

ここに, $U_{*}$ は摩擦速度, $h$ は水深であり, $U_{*}$ は,

$$
U_{*} \fallingdotseq \frac{\left|v e l_{x}\right|}{20.0}
$$

で近似した.

計算上で仮想ゴミ（質量がゼロの粒子）を用いて漂流 ゴミの輸送を算定した．拡散状況はランダムウォークの 不確定性に着目し，正規乱数を用いたモンテカルロ法》 により求めた。 流入源は湾内に流入する主要流入河川 (多摩川，隅田川，荒川，鶴見川）とし，それぞれの河 口付近のHFレーダー観測点（図-2の解析点 (•)）から放 流した。また，陸域に到着した仮想ゴミについては, 個々にその時点で計算を終了した. 図-5に, 計算結果の 例を示寸．この例は，2006年8月9日17時に，荒川の河口 付近（印印の地点）から1000個の粒子を放流したもので あり，2006年8月10日16時のゴミ回収作業時における， 粒子の分布状況を示したものである.

放流河川 From Arakawa Time period: 23 h追跡時間 放流日時 2006/8/9 17:00 8/10 16:00 回収作業日時

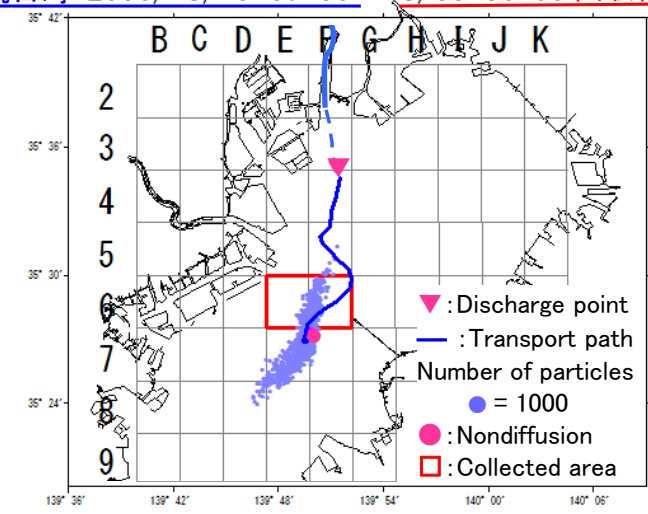

図-5 仮想ゴミの輸送計算結果の例（回収日：2006年8月10日） 


\section{（2）流入期間の推定方法}

計算上で，湾内に仮想ゴミを放流し，放流日時から 1 時間毎のタイムステップで輸送計算をする．仮想ゴミの 流れによる輸送には，放流日時における，放流地点付近 のHFレーダー観測流速から算出した推定流速を与えて 計算する．したがって同一の放流地点でも放流日時が異 なれば，推定流速の算出に用いるHFレーダー観測流速 が異なるので, 計算結果も異なる. 例として図-6に, 漂 流ゴミ回収日：2006年8月 10日の回収作業時（10〜16 時）に対し，荒川の河口から1000個の粒子を，放流日時 を8月9日16時〜20時まで1時間毎に変化させて放流した 仮想ゴミ輸送経路図を示す。このように各漂流ゴミ回収 日に対し，放流日時を変化させて仮想ゴミの輸送計算を 行い，輸送経路と漂流分布を算出する．そして「べいく りん」の漂流ゴミ回収作業時の回収エリアに，仮想ゴミ が漂流する放流日時の期間を推定流入期間とした. 図-6 の例では2006年8月9日17〜19時（図-6のB〜D）に放流し た仮想ゴミが回収エリアに漂流している。これより2006 年8月10日の回収日における荒川からの漂流ゴミ推定流 入期間は 8 月 9 日 $17 〜 19$ 時と推定できた. 同様に各漂流ゴ ミ回収日につき, 流入河川毎の推定流入期間を算出した.

from Arakawa time period: $24 \mathrm{~h}$ from Arakawa time period: $23 \mathrm{~h}$ 2006 8/9/16:00 8/10/16:00 2006 8/9/17:00 8/10/16:00

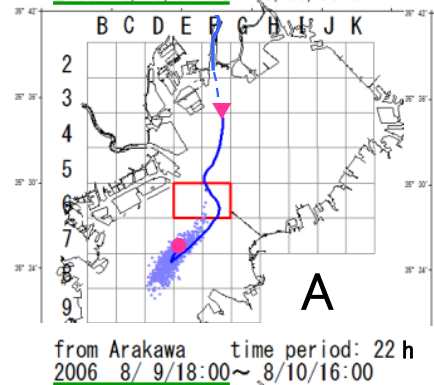
$B C D E F$ G DUd J $K$

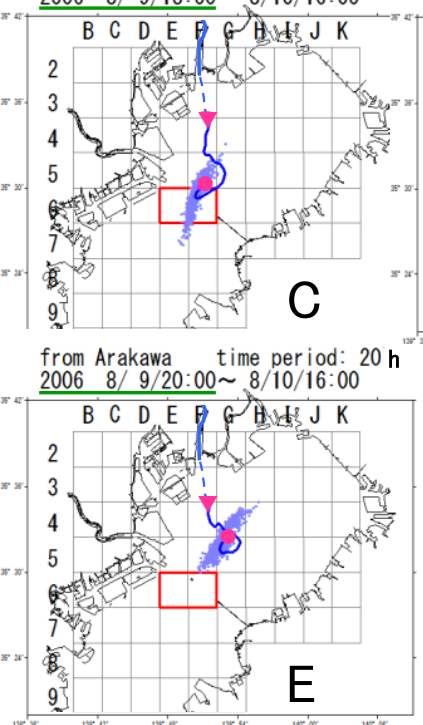

$\nabla:$ Discharge point : Transport path Number of particles $=1000$

: Nondiffusion $\square$ : Collected area

図-6 放流日時の変化による仮想ゴミ輸送経路図の変化（回収 日：2006年8月 10 日）

\section{5. 計算結果と考察}

算出した推定流入期間の一例を表-2に示す．表-2は 2006年9月27日，28日の各漂流ゴミ回収日における，流 入河川とその流入期間の推定結果である．表中の斜線部 は，放流日時を変化させて流入河川から仮想ゴミを放流 したが，回収エリアへ漂流が確認されなかったため，そ の河川からの流入は無しとしたことを意味する．表-2よ り，2006年9月27日の回収日は，推定流入河川は多いが 回収量は少なく，対して2006年9月28日の回収日は，推 定流入河川は少ないが回収量は多いことが分かる.

回収日：2006年9月28日について仮想ゴミ輸送計算を 行ったところ，漂流ゴミ回収データと良い一致が確認で きた. 表-3に「べいくりん」による当日の回収作業の詳 細を，図一7推定流入河川毎の仮想ゴミ輸送経路を示す。

表-2 推定流入河川とその推定流入期間（回収日 : 2006年9月27 日，28日）

\begin{tabular}{|c|c|c|c|c|c|c|c|}
\hline \multirow{2}{*}{$\begin{array}{c}\text { Collected } \\
\text { date }\end{array}$} & \multirow{2}{*}{ Volume } & \multicolumn{6}{|c|}{ Estimated inflow duration } \\
\hline & & \multicolumn{2}{|c|}{ Tamagawa } & \multicolumn{2}{|c|}{ Sumidagawa } & \multicolumn{2}{|l|}{ Arakawa } \\
\hline $2006 / 9 / 27$ & $0.4 \mathrm{~m}^{3}$ & $\begin{array}{l}9 / 26 \text { 21:00 } \\
\text { 9/26 23:00 }\end{array}$ & $2 \mathrm{~h}$ & $\begin{array}{lll}9 / 26 & 16: 00 \\
9 / 26 & 21: 00\end{array}$ & $5 \mathrm{~h}$ & \begin{tabular}{|rr}
$9 / 26$ & $8: 00$ \\
9 & 5 \\
$9 / 26$ & $11: 00$
\end{tabular} & $3 \mathrm{~h}$ \\
\hline $2006 / 9 / 28$ & $24.49 \mathrm{~m}^{3}$ & & & $\begin{array}{l}9 / 2720: 00 \\
5 / 2723: 00\end{array}$ & $3 \mathrm{~h}$ & $\begin{array}{|rr|}9 / 27 & 9: 00 \\
\text { S } & \\
9 / 27 & 12: 00 \\
\end{array}$ & $3 \mathrm{~h}$ \\
\hline
\end{tabular}

表-3「べいくりん」により回収された漂流ゴミの詳細（回収 日：2006年9月28日）

\begin{tabular}{|c|c|c|c|c|}
\hline 場所選択 & \multicolumn{4}{|c|}{$\mathrm{F} 4$} \\
\hline \multirow{8}{*}{ 回収物 } & \multicolumn{4}{|c|}{\begin{tabular}{l|l}
$0 \mathrm{~m}^{3}$ & 2)木片 \\
\end{tabular}} \\
\hline & 3)ビニール類 & $0.1 \mathrm{~m}^{3}$ & 4)ビン·カン & 3個 \\
\hline & 5)ゴム類(タイヤ大) & o個 & 6)ゴム類(タイヤ小) & 0個 \\
\hline & 7)葦·草 & $0 \mathrm{~m}^{3}$ & 8)海藻類 & $0 \mathrm{~m}^{3}$ \\
\hline & 9)竹 & $0 \mathrm{~m}^{3}$ & 10)発泡スチロール & $0 \mathrm{~m}^{3}$ \\
\hline & 11)鉄製品(冷蔵庫) & 0個 & 12)鉄製品(テレビ) & 0個 \\
\hline & 13)鉄製品(洗濯機) & 0個 & 14)鉄製品(ボンベ類) & 0本 \\
\hline & 15)鉄製品(その他) & 0 & 16)その他 & 0 \\
\hline \multicolumn{5}{|c|}{ ゴミ回収データPM } \\
\hline 場所選択 & \multicolumn{4}{|c|}{ F5 } \\
\hline \multirow{8}{*}{ 回収物 } & 1)木材 & $3 \mathrm{~m}^{3}$ & 2)木片 & $4 \mathrm{~m}^{3}$ \\
\hline & 3)ビニール類 & $0 \mathrm{~m}^{3}$ & 4)ビン·カン & 0個 \\
\hline & 5)ゴム類(タイヤ大) & 0個 & 6)ゴム類(タイヤ小) & 0個 \\
\hline & 7)葦·草 & $7 \mathrm{~m}^{3}$ & 8)海藻類 & $0 \mathrm{~m}^{3}$ \\
\hline & 9)竹 & $10 \mathrm{~m}^{3}$ & 10)発泡スチロール & $0 \mathrm{~m}^{3}$ \\
\hline & 11)鉄製品(冷蔵庫) & 0個 & 12)鉄製品(テレビ) & 0個 \\
\hline & 13)鉄製品(洗濯機) & 0個 & 14)鉄製品(ボンベ類) & 0本 \\
\hline & 15)鉄製品(その他) & 0 & 16)その他 & 0 \\
\hline
\end{tabular}

作業明細
\begin{tabular}{|c|c|c|c|c|c|}
\hline 始業(時:分) & 終業(時:分) & 時間(分) & 航行距離(km) & \multicolumn{2}{|c|}{ 記事 } \\
\hline $8: 30$ & $9: 00$ & 30 & 0 & 運転準備 & \\
\hline $9: 00$ & $10: 20$ & 80 & 23 & 沖航 & 基地 F5 \\
\hline $10: 20$ & $12: 15$ & 115 & 12 & 回収 & F5, F4 \\
\hline $12: 15$ & $13: 00$ & 45 & 0 & 沖航 & \\
\hline $13: 00$ & $15: 40$ & 160 & 16 & 回収 & F4, F5 \\
\hline $15: 40$ & $17: 00$ & 80 & 23 & 沖航 & F6 0 基地 \\
\hline $17: 00$ & $17: 20$ & 20 & 0 & 係留作業 & \\
\hline $17: 20$ & $18: 00$ & 40 & 0 & 清掃片付 & \\
\hline
\end{tabular}



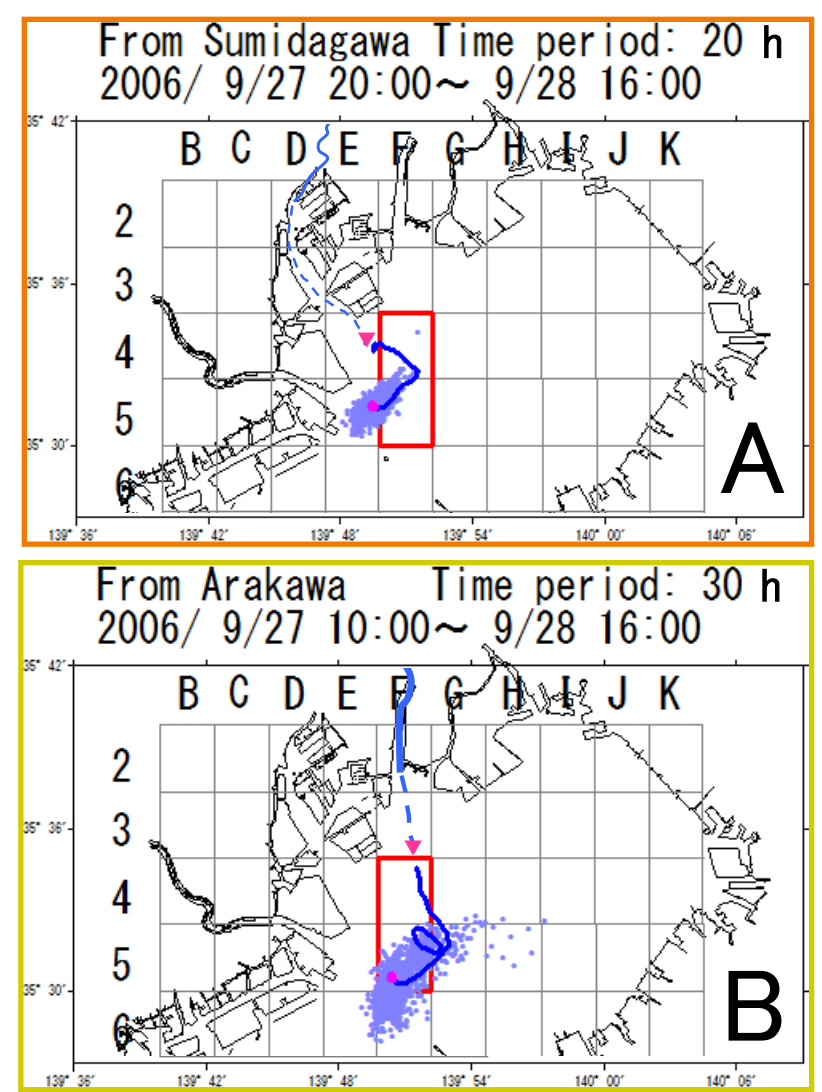

Discharge date and time
A: 2006/9/27 20:00
B : 2006/9/27 10:00
— : Transport path Number of particles $=1000$
: Nondiffusion
$\square$ : Collected area

図-7 推定流入河川毎の仮想ゴミ輸送経路（回収日：2006年9月 28日）

表-3より，この回収日はF5 $\rightarrow F 4 \rightarrow F 5$ と回収エリアを航 行して回収を行い，回収された漂流ゴミの大部分がF5の 回収エリアにおいて回収されたことが分かる. そこで, 図-8に示すように，仮想ゴミの輸送経路・漂流分布を算 出し, 回収作業明細より推定した「べいくりん」の航路 と確認した. 図-7より，どちらの放流河川からの仮想ゴ ミも，F4の回収エリアを通過した後，F5の回収エリアに 漂流し広く分布していることが確認できる．図-8におい ても, 推定航路の後半は仮想ゴミの分布形状とよく一致 している. したがって, この輸送計算結果は回収記録と 整合性があると考えられる.

また，この回収日の回収エリア(F4,F5)は多摩川の河口 に近い，計算の都合上，放流地点を流入河川の河口付近 にしているため, 多摩川からの漂流ゴミ輸送経路，及び 流入期間の推定は困難である. しかし河口に近いという ことは，回収作業時に流入してきたゴミも回収されてい ると考えられる．したがって多摩川も，この回収日にお ける推定流入河川であると言える.

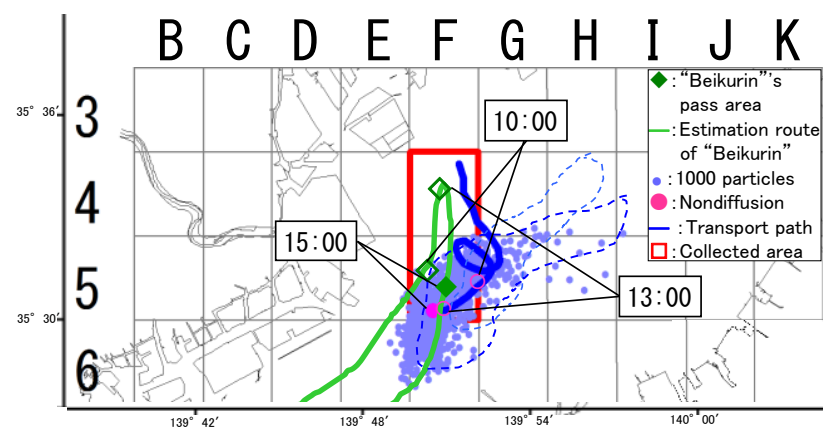

図-8 仮想ゴミの輸送経路・漂流分布と「べいくりん」の推定 航路（回収日：2006年9月28日，放流河川 : 荒川，放流日 時 : 2006年9月27日10時)

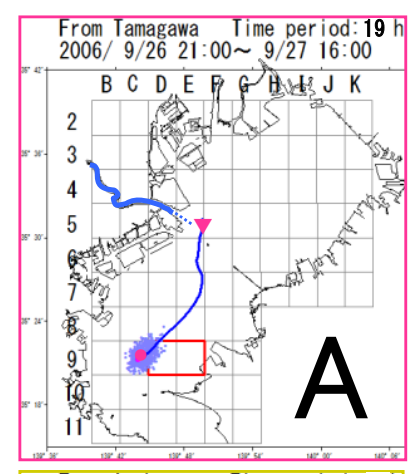

From Arakawa Time period: $32 \mathrm{~h}$
$2006 / 9 / 26$ 8:00 9/27 16:00

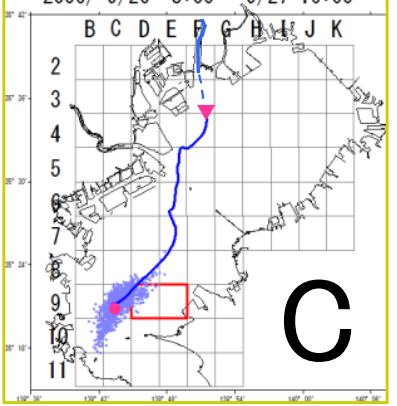

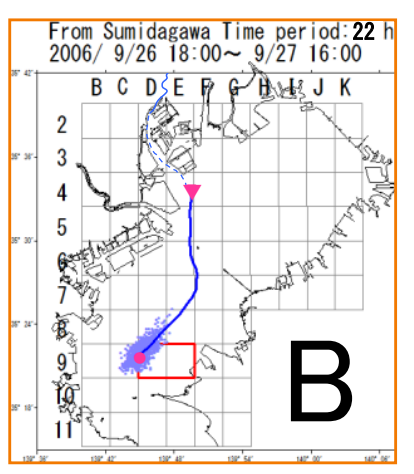

Discharge date and time

A: 2006/9/26 21:00

B : $2006 / 9 / 2618: 00$

C: $: 2006 / 9 / 26 \quad 8: 00$

$\nabla:$ Discharge point

— : Transport path

Number of particles $=1000$

: Nondiffusion

$\square$ : Collected area
図-9 推定流入河川毎の仮想ゴミ輸送経路（回収日：2006年9月 27日）

計算結果と漂流ゴミ回収記録の整合性が良いことや, 多摩川からの流入も考慮できるので，推定流入河川は少 なかったが，回収量は多かった原因が明らかになった。

同様に2006年9月27日の漂流ゴミ回収について，計算 結果と漂流ゴミ回収データを比較したが，良い一致は確 認できなかった. 図-9に推定流入河川毎の仮想ゴミ輸送 経路を，表-4に「べいくりん」の漂流ゴミ回収記録にお ける当日の回収作業の明細を示す，表-4より，「べい りん」がF8 $\rightarrow \mathrm{E} 9 \rightarrow \mathrm{D} 9$ と回収エリアを航行していたこと が分かる．これより図-10に示すように，仮想ゴミの輸 送経路が，「べいりん」の推定航路と一致しない結果 であった，原因はまだ不明であり，したがって計算モデ ル，推定方法の改良が今後の課題である. 
表-4「べいくりん」による回収作業の明細（回収日：2006年9 月27日）

作業明細
\begin{tabular}{|c|c|c|c|c|c|}
\hline 始業(時:分) & 終業(時: 分) & 時間(分) & 航行距離(km) & \multicolumn{2}{|c|}{ 記事 } \\
\hline $8: 30$ & $9: 00$ & 30 & 0 & 運転準備 & \\
\hline $9: 00$ & $10: 10$ & 70 & 21 & 沖航 & 基地 F8 \\
\hline $10: 10$ & $12: 15$ & 125 & 13 & 回収 & F8, E9 \\
\hline $12: 15$ & $13: 00$ & 45 & 0 & 待機 & \\
\hline $13: 00$ & $15: 50$ & 170 & 17 & 回収 & E9, D 9 \\
\hline $15: 50$ & $17: 00$ & 70 & 20 & 沖航 & D9 基地 \\
\hline $17: 00$ & $17: 20$ & 20 & 0 & 係留作業 & \\
\hline $17: 20$ & $18: 00$ & 40 & 0 & 清掃片付 & \\
\hline
\end{tabular}

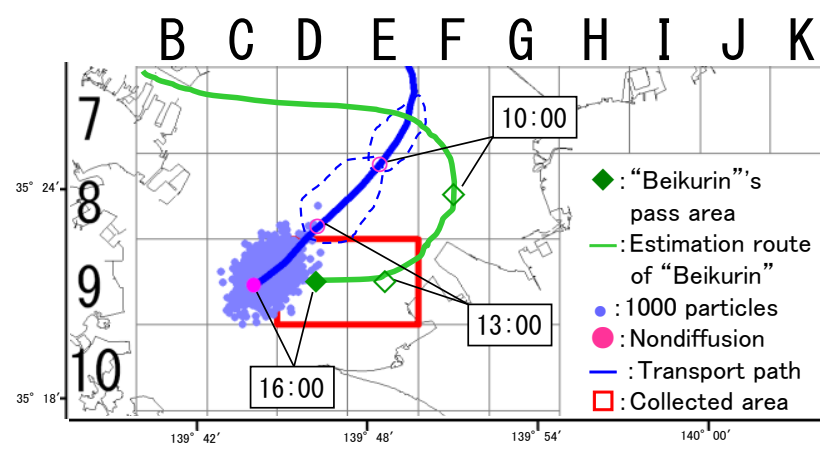

図-10 仮想ゴミの輸送経路・漂流分布と「べいくりん」の推定 航路（回収日：2006年9月27日，放流河川：多摩川，放流 日時 : 2006年9月26日21時)

\section{6. 結論}

本研究では東京湾を対象海域とし，国土交通省により 沿岸に設置されているHFレーダーの観測結果と, 同省 の清掃兼油回収船「べいくりん」による回収記録を用い て，漂流ゴミの輸送経路・流入期間を推定した．漂流ゴ ミの輸送を移流拡散現象として仮想ゴミ（質量の無い粒 子）を用いて算定し，放流日時を変化させて計算するこ とにより流入期間の推定を行った. その結果から得られ
た結論を以下に記す。

・漂流ゴミ回収船「べいくりん」により回収された漂 流ゴミの輸送経路・流入期間が推定でき，回収記録に ある回収量の多少や「べいくりん」の推定航路との比 較等から，回収記録との整合性も概ね良好であった。 ・HFレーダーの表層流況データによる，漂流ゴミの輸 送経路の予測，及び予測結果の漂流ゴミ回収への利用 の可能性が示唆された。

謝辞：本研究を進めるに当たり，「べいくりん」による 漂流ゴミ回収記録は国土交通省様関東地方整備局千葉港 湾事務所より使用させて頂きました．関係者の皆様には 深く感謝申し上げます.

\section{参考文献}

1）戀塚貴 : ゴミのない美しい海を目指して－漂流・漂 着ゴミの現状と対策一, 国土技術政策総合研究所講 演会講演集，第 614 号，pp.99-118，2010

2) 二瓶泰雄, 若月宣人 : 洪水時河川における浮遊ゴミ 輸送量計測の試み，土木学会論文集 B，Vol.66，No.1， pp.19-24, 2010.

3) 小澤裕介, 阿久津匠市, 村上和男: 海洋短波レーダ 一による潮流測点と表層流の海上風による影響の平 面分布特性，海洋開発論文集第 27 巻， 2011 .

4) 国土交通省 中部地方整備局 名古屋港湾空港技術調査 事務所：浮遊ゴミ移動予測システム高度化検討業務, 平成 21 年度名古屋技調報告, pp.74-79, 2009 .

5）東京湾環境情報センター : http://www.tbeic.go.jp/ (最終アクセス日 : 2012.03.29)

6) 片岡智哉, 日向博文: 東京湾における推定ゴミ流入 量の水平拡散係数に対する依存性，国土技術政策総 合研究所研究資料，第 627 号，pp.1-17，2011

7) 堀江毅：沿岸海域の水の流れと物質の拡散に関する 水理学的研究, 港湾空港技術研究所資料, No.360, pp.169-181, 1980.

\title{
THE ESTIMATED INFLOW PERIOD AND TRANSPORT ROUTES OF DRIFTING GARBAGE IN TOKYO BAY BY HFRADAR
}

\author{
Takumi MORIYA and Kazuo MURAKAMI
}

Drifting garbage on the sea has a bad influence on economic activity and on coastal environment. Therefore, it is necessary to collect the garbage quickly and to understand the discharged source and the transport route are very important. On this study, the source and route of the garbage were analyzed by using the surface current data obtained by HF Radar and the collection records of garbage by garbage collection ship of the "Beikurin". The discharge date and location were estimated by using results of the convection and diffusion phenomena of 1,000 virtual trashes. Comparison with estimated results and the garbage collection records, reasonable results of discharged location and duration were obtained. From the results, it is suggested that surface current data by HF Radar has applicability to the garbage collection system. 